\title{
高レベル放射性廃液模擬環境でのステンレス鋼腐食に及ぼす 減圧沸騰の影響*
}

\author{
入澤恵理子 ${ }^{* *}$, 上野文義 ${ }^{* *}$, 加藤千明**, 阿部 仁 $^{* *}$ \\ ** 国立研究開発法人日本原子力研究開発機構
}

Effect of Boiling under Reduced Pressure on Corrosion of Stainless Steels in Nitric Acid Solution
Simulating High-level Radioactive Liquid Waste*

Eriko Irisawa** $^{*}$, Fumiyoshi Ueno** ${ }^{*}$ Chiaki Kato** and Hitoshi Abe ${ }^{* *}$

** Japan Atomic Energy Agency

\begin{abstract}
In order to investigate the effect of boiling under reduced pressure on corrosion of stainless steel in the nitric acid solution, the corrosion tests simulating the high-level radioactive liquid waste evaporator were performed. The results of immersion tests of stainless steels in the solution with and without boiling showed that the corrosion rates in boiling solution were larger than those in not boiling solution in case of same temperature of solution. Moreover, the cathode polarization curves showed that the corrosion potential of stainless steel in boiling solutions were shifted nobler, and the current intensity became larger than that in not boiling solutions. According to these results, it can be concluded that boiling of solution under reduced pressure accelerate the corrosion rates.
\end{abstract}

Key words : nuclear fuel reprocessing, nitric acid, corrosion of stainless steel, oxidizing metallic ion, boiling under reduced pressure

1. 緒言

使用済核燃料再処理施設では，使用済燃料を硝酸溶液 に溶解し処理する。この再処理プロセス溶液は，硝酸濃 度が高く，使用済燃料由来の酸化性金属イオン $(\mathrm{Pu}$, $\mathrm{Np}, \mathrm{Ru}, \mathrm{Ce}$ など)が溶解しており，高い腐食性を有し ている。 そのため, 再処理施設で用いられているステン レス鋼製機器において粒界腐食が懸念される ${ }^{1)}$. 酸化性 金属イオン濃度が高くなる高レベル廃液濃縮缶では, 腐 食環境を緩和するために運転温度を低くすることを目的 に, 缶内を減圧し溶液を沸騰させる運転を行っている ${ }^{2)}$. このように，様々な腐食影響因子が混在する複雑な腐食 環境においては, 腐食進展を予測することが機器の運転 管理上重要であり，特に腐食を加速させる因子の把握が 必要である.

これまでに硝酸溶液中におけるステンレス鋼腐食に関 して様々な研究が行われてきたが，溶液の沸騰とステン レス鋼腐食の関係について検討した事例は少ない。上野 らは, バナジゥム $(\mathrm{V})$ を模擬酸化性金属イオンとして用 いた溶液中のステンレス鋼腐食試験を行い, 沸騰の有無 により腐食速度温度依存性に違いが生じる可能性を示し た ${ }^{3)}$. また, 梶村らは沸騰により硝酸の酸化還元電位が 上昇することを報告している ${ }^{4)}$ 。いずれも，沸騰よる腐食 挙動の変化を示唆しているが, 直接評価した報告はない。

そこで本研究では, 高レベル廃液濃縮缶の運転環境を 模擬した試験によりステンレス鋼腐食に及ぼす沸騰の有 無の影響を評価することを目的とし，大気圧下および減

* 第 62 回材料と環境討論会(福岡, 2015 年) で一部発表

** ₹ 319-1195 那珂郡東海村大字白方 2-4(2-4, Oaza-shirakata, Tokaimura, Naka-gun, 319-1195 Japan)
圧沸騰下での非放射性模擬高レベル廃液を用いた浸漬腐 食試験を行い，電気化学試験結果とともに考察した。

\section{2. 実 験 方 法}

\section{1 試験片}

試験材料には, 実機材相当の極低炭素オーステナイト 系ステンレス鋼 R-SUS304ULC 鋼 ${ }^{5}$ を用いた。試験に用 いた R-SUS304ULC 鋼の化学組成を Table 1 に示す。試 験片は高さ $10 \mathrm{~mm} \times$ 幅 $10 \mathrm{~mm} \times$ 厚さ $5 \mathrm{~mm}$ に切り出し た物を使用し, 浸漬腐食試験用には保持用の穴を, 電気 化学試験用には導電棒を取り付けるためのネジ穴をそれ ぞれ設けた。いずれの試験片も，\#1200で湿式研磨し, エタノールを用いて超音波洗浄した後, 試験に用いた。

\section{2 試験溶液}

高レベル廃液濃縮缶は, 液の注入, 濃縮後の液の払出 しまで一連のバッチ運転で行われており ${ }^{6}$, 濃縮終了時 の廃液 (以下, 濃縮液) 中で酸化性イオン濃度が最も高く なり腐食性が高まると予想される。 そこで本研究では, この濃縮液組成を以下のように推定し, 試験に用いた。

まず，公開情報 ${ }^{7)}$ に記載されている実機設計時に考慮し た使用済燃料は，加圧水型原子炉(PWR) 用で燃焼度 45,000 MWd/tU，冷却期間 1,200 日のものである．それと同 等の条件(ウラン濃縮度 4.5\%, 燃焼度 $45,000 \mathrm{MWd} / \mathrm{tHM}$,

Table. 1 Chemical composition of R-SUS304ULC used in this study (mass\%)

\begin{tabular}{|c|c|c|c|c|c|c|c|}
\hline $\mathrm{Fe}$ & $\mathrm{Cr}$ & $\mathrm{Ni}$ & $\mathrm{Mn}$ & $\mathrm{Si}$ & $\mathrm{P}$ & $\mathrm{S}$ & $\mathrm{C}$ \\
\hline Bal. & 18.43 & 10.63 & 1.11 & 0.38 & 0.012 & 0.002 & 0.009 \\
\hline
\end{tabular}


冷却期間 5 年)で, ORIGEN-2.2-UPJ および JENDLE3.3に 基づくライブラリ ORIBJ33 を用いて算出された使用済燃料 組成が Table 2 のように報告されており ${ }^{8)}$ ，この使用済燃料 $1 \mathrm{t}$ を硝酸水溶液中に溶解し処理すると仮定した。

燃料が溶解した硝酸溶液は, 分離・抽出工程において

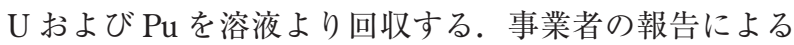
と, U は全量, $\mathrm{Pu}$ は $99.7 \%{ }^{9)}$ 回収されると報告しており, 本研究でもこの回収率を採用した。

分離回収された以外の燃料固体成分が溶解している抽 出廃液は, 高レベル廃液濃縮缶に流入し, 加熱, 濃縮す ることで濃縮液となる。事業者らが実液相当として試験 に用いた濃縮液濃度の一部を Table 3 に示す ${ }^{7)}$ 。これと 本研究で仮定した使用済燃料 $1 \mathrm{t}$ 中の組成 (Table 2) を比 較すると，使用済燃料 $1 \mathrm{t}$ を処理した場合に平均 $252 \mathrm{dm}^{3}$ の濃縮液を得ると算出される。そこで本研究では, 使用 済燃料 $1 \mathrm{t}$ を処理すると $252 \mathrm{dm}^{3}$ の高レベル廃液が出来 ると仮定して，濃縮液組成を Table 4 に決定した。

硝酸濃度は Table 3 と同等の $8.0 \mathrm{~mol} / \mathrm{dm}^{3}(\mathrm{M})$ とし, $\mathrm{Fe}$ および $\mathrm{Cr}$ は主に濃縮工程においてステンレス鋼表面 より溶液へ溶解したと考えた。 Fe 濃度は Table3 に示す 濃度 $4.98 \mathrm{~g} / \mathrm{dm}^{3}$ を, Cr 濃度は R-SUS304ULC 鋼の重量 組成比が約 70:18.5 であることを考慮して $1.3 \mathrm{~g} / \mathrm{dm}^{3}$ と設 定した。

本研究では, この濃縮液に含有する金属成分のうち, $\mathrm{HNO}_{3} / \mathrm{HNO}_{2}$ 平衡反応の標準酸化還元電位 $E_{0}=0.96 \mathrm{~V}(298$ K) vs. NHE よりも十分に低いものは腐食に寄与しないと 考え除外し，これまでに腐食に寄与すると報告のある $\mathrm{Ru}, \mathrm{Ce}, \mathrm{Fe}, \mathrm{Cr}, \mathrm{Np}, \mathrm{Pu}$ について考慮することとした 1),10),11). $\mathrm{Pu}$ および $\mathrm{Np}$ は，標準酸化還元電位が $\mathrm{PuO}_{2}{ }^{2+} /$ $\mathrm{Pu}^{4+}$ 平衡反応 $\left(E_{0}=1.042 \mathrm{~V}(298 \mathrm{~K}) \mathrm{vs} . \mathrm{NHE}\right)$ と近いこと ${ }^{12)}$ や腐食への効果に対する過去の知見 ${ }^{13)}$ を参考にバナジウ ム $(\mathrm{V})$ を模擬物質に用いた。 以上より，試験には Table 5 に示すような組成の溶液を用いた，硝酸ネオジムは，溶 液中の総 $\mathrm{NO}_{3}{ }^{-}$濃度を実液相当の $10.5 \mathrm{M}$ とするために添 加した.

Table. 2 Compositions of spent fuels for simulating of high active liquid west (HALW) in this study $\left(\mathrm{g} / \mathrm{tHM}^{*}\right)^{8)}$

\begin{tabular}{|c|c|c|c|c|c|c|c|}
\hline $\mathrm{H}$ & $5.75 \times 10^{-2}$ & $\mathrm{Tc}$ & $1.03 \times 10^{3}$ & $\mathrm{I}$ & 298 & $\mathrm{Eu}$ & 188 \\
\hline $\mathrm{Se}$ & 77.3 & $\mathrm{Ru}$ & $3.00 \times 10^{3}$ & $\mathrm{Xe}$ & $7.16 \times 10^{3}$ & $\mathrm{Gd}$ & 171 \\
\hline $\mathrm{Br}$ & 28.3 & $\mathrm{Rh}$ & 576 & $\mathrm{Cs}$ & $3.55 \times 10^{3}$ & $\mathrm{~Tb}$ & 3.24 \\
\hline $\mathrm{Kr}$ & 540 & $\mathrm{Pd}$ & $1.86 \times 10^{3}$ & $\mathrm{Ba}$ & $2.25 \times 10^{3}$ & $\mathrm{Dy}$ & 1.64 \\
\hline $\mathrm{Rb}$ & 521 & $\mathrm{Ag}$ & 108 & $\mathrm{La}$ & $1.64 \times 10^{3}$ & $\mathrm{U}$ & $9.41 \times 10^{5}$ \\
\hline $\mathrm{Sr}$ & $1.13 \times 10^{3}$ & $\mathrm{Cd}$ & 135 & $\mathrm{Ce}$ & $3.27 \times 10^{3}$ & $\mathrm{~Np}$ & 659 \\
\hline $\mathrm{Y}$ & 632 & $\mathrm{In}$ & 1.86 & $\mathrm{Pr}$ & $1.50 \times 10^{3}$ & $\mathrm{Pu}$ & $1.15 \times 10^{4}$ \\
\hline $\mathrm{Zr}$ & $4.91 \times 10^{3}$ & $\mathrm{Sn}$ & 78.8 & $\mathrm{Nd}$ & $5.49 \times 10^{3}$ & $\mathrm{Am}$ & 569 \\
\hline $\mathrm{Nb}$ & $4.59 \times 10^{-3}$ & $\mathrm{Sb}$ & 15.4 & $\mathrm{Pm}$ & 56.3 & $\mathrm{Cm}$ & 43.4 \\
\hline $\mathrm{Mo}$ & $4.55 \times 10^{3}$ & $\mathrm{Te}$ & 650 & $\mathrm{Sm}$ & $1.07 \times 10^{3}$ & & \\
\hline
\end{tabular}

thM is total weight of fission products and actinides

Table. 3 Concentration of some components in actual HALW ${ }^{7)}$

\begin{tabular}{|c|c|c|c|c|}
\hline $\mathrm{H}^{+}\left(\mathrm{mol} / \mathrm{dm}^{3}\right)$ & $\mathrm{Fe}\left(\mathrm{g} / \mathrm{dm}^{3}\right)$ & $\mathrm{Ru}\left(\mathrm{g} / \mathrm{dm}^{3}\right)$ & $\mathrm{Ce}\left(\mathrm{g} / \mathrm{dm}^{3}\right)$ & $\mathrm{Np}\left(\mathrm{g} / \mathrm{dm}^{3}\right)$ \\
\hline 8.1 & 4.98 & 11.8 & 13.9 & 2.46 \\
\hline
\end{tabular}

Table. 4 Composition of HALW simulated in this study (M)

\begin{tabular}{|c|c|c|c|c|c|c|c|}
\hline $\mathrm{HNO}_{3}$ & 8.0 & $\mathrm{Ru}$ & $1.18 \times 10^{-1}$ & $\mathrm{Cs}$ & $1.06 \times 10^{-1}$ & $\mathrm{Gd}$ & $4.32 \times 10^{-3}$ \\
\hline $\mathrm{Se}$ & $3.88 \times 10^{-3}$ & $\mathrm{Rh}$ & $2.22 \times 10^{-2}$ & $\mathrm{Ba}$ & $6.50 \times 10^{-2}$ & $\mathrm{~Tb}$ & $8.09 \times 10^{-5}$ \\
\hline $\mathrm{Rb}$ & $2.42 \times 10^{-2}$ & $\mathrm{Pd}$ & $6.94 \times 10^{-2}$ & $\mathrm{La}$ & $4.69 \times 10^{-2}$ & $\mathrm{Dy}$ & $4.05 \times 10^{-5}$ \\
\hline $\mathrm{Sr}$ & $5.12 \times 10^{-2}$ & $\mathrm{Ag}$ & $3.97 \times 10^{-3}$ & $\mathrm{Ce}$ & $9.26 \times 10^{-2}$ & $\mathrm{~Np}$ & $1.10 \times 10^{-2}$ \\
\hline $\mathrm{Y}$ & $2.82 \times 10^{-2}$ & $\mathrm{Cd}$ & $4.77 \times 10^{-3}$ & $\mathrm{Pr}$ & $4.22 \times 10^{-2}$ & $\mathrm{Pu}$ & $5.61 \times 10^{-4}$ \\
\hline $\mathrm{Zr}$ & $2.14 \times 10^{-1}$ & $\mathrm{In}$ & $6.43 \times 10^{-5}$ & $\mathrm{Nd}$ & $1.51 \times 10^{-1}$ & $\mathrm{Am}$ & $9.29 \times 10^{-3}$ \\
\hline $\mathrm{Nb}$ & $1.96 \times 10^{-7}$ & $\mathrm{Sn}$ & $2.63 \times 10^{-3}$ & $\mathrm{Pm}$ & $1.54 \times 10^{-3}$ & $\mathrm{Cm}$ & $6.97 \times 10^{-4}$ \\
\hline $\mathrm{Mo}$ & $1.88 \times 10^{-1}$ & $\mathrm{Sb}$ & $5.02 \times 10^{-4}$ & $\mathrm{Sm}$ & $2.82 \times 10^{-2}$ & $\mathrm{Fe}^{*}$ & $8.95 \times 10^{-2}$ \\
\hline $\mathrm{Tc}$ & $4.17 \times 10^{-2}$ & $\mathrm{Te}$ & $2.02 \times 10^{-2}$ & $\mathrm{Eu}$ & $4.91 \times 10^{-3}$ & $\mathrm{Cr}^{*}$ & $2.50 \times 10^{-2}$ \\
\hline
\end{tabular}

"Corrosion products

Table. 5 Composition of test solution (M)

\begin{tabular}{|c|c|c|c|c|c|c|}
\hline $\mathrm{HNO}_{3}$ & $\mathrm{Ru}$ & $\mathrm{Ce}$ & $\mathrm{V}$ & $\mathrm{Fe}$ & $\mathrm{Cr}$ & $\mathrm{Nd}\left(\mathrm{NO}_{3}\right)_{3}$ \\
\hline 8.0 & 0.118 & 0.11 & 0.012 & 0.090 & 0.025 & 1.9 \\
\hline
\end{tabular}

\section{3 試験手順}

浸漬腐食試験は, 還流冷却器を接続したセパラブルフ ラスコを用いて実施した. フラスコ内で試験片 2 個を試験 溶液 $0.2 \mathrm{dm}^{3}$ 中に $\mathrm{Zr}$ ワイヤーを用いて浸漬させ，マント ルヒーターで加熱した.このとき比液量は $25 \mathrm{~mL} / \mathrm{cm}^{2}$ で あった，溶液温度は，実機で測定実績のある温度範囲 ${ }^{14)}$ を考虑し，328，353 および $383 \mathrm{~K}$ とした。また，内部の 圧力はそれぞれ大気圧および各温度での飽和圧力 $(6.6$ $\mathrm{kPa}(328 \mathrm{~K}), 22.7 \mathrm{kPa}(353 \mathrm{~K}), 55.3 \mathrm{kPa}(373 \mathrm{~K}))$ とした. 減圧条件での試験時は, 還流冷却器上部よりポンプに接 続し，系内を所定の圧力に保持した。試験時間は 1 バッ チ 240 時間，合計 5 バッチ実施した。試験片は 5 バッチ 通して同じ試験片を継続して用い, 各バッチ後にエタノ ールで超音波洗浄後，重量測定および操作電子顕微鏡 (SEM) による表面観察を行った. 試験液はバッチごとに 更新した.

電気化学測定には, 浸漬腐食試験と同様に還流器を接 続したセパラブルフラスコを用いた。試験液量は $0.4 \mathrm{dm}^{3}$ とした。このときの比液量は $40 \mathrm{~mL} / \mathrm{cm}^{2}$ である. 飽和塩 化カリウム溶液を内部液とした銀塩化銀電極を参照電極 とし，60\%硝酸を充填したガラス製液絡連結管内に浸漬 し, 試験液と接続した。作用極は $\mathrm{Zr}$ 製導電棒を装着し た試験片を用いた。ポテンショスタットを用いて 2 時間 自然浸漬電位 $(\mathrm{OCP})$ を測定した後, OCPより+0.05 Vか ら $0.33 \mathrm{mV} / \mathrm{sec}$ でカソード分極曲線を, OCPより-0.05 V から $0.33 \mathrm{mV} / \mathrm{sec}$ でアノード分極曲線をそれぞれ取得し た。

\section{3. 結果}

\section{1 試験後の表面観察}

Fig. 1 に 1 バッチ目の腐食試験後の表面 SEM 像を示 す.いずれの温度においても粒界腐食の形跡が見られる. $328 \mathrm{~K}$ では, 1 バッチ目は粒界腐食に留まり, 脱粒はあ まり観察されない. しかし, バッチ試験を重ね, 腐食時 間が増加すると脱粒が確認されるようになった．温度が 高くなると, 腐食の進行が速くなるので, 結晶粒の母材 


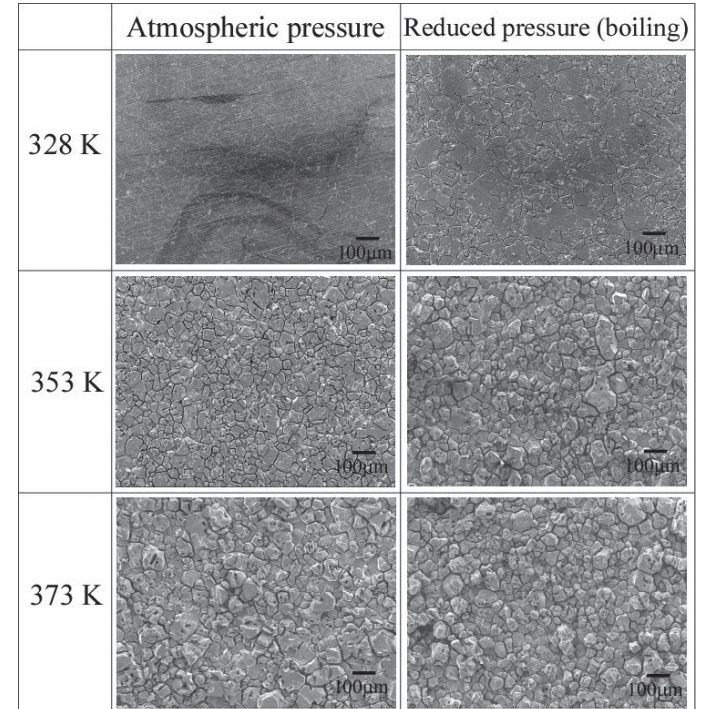

Fig. 1 SEM images of sample surfaces after immersion test of first batch (240 hours).

からの脱落が 1 バッチ目から観察された。また，粒界腐 食およびその進行による結晶粒の脱落という腐食形態に 対しては，沸騰の有無の影響は見られなかった。

\section{2 腐食速度の温度依存性}

バッチごとの重量減少より算出した区間腐食速度 $(\mathrm{g} /$ $\mathrm{m}^{2} \mathrm{~h}$ )について，5バッチ全ての腐食速度の温度依存性を Fig.2 に示す。腐食反応を一つの化学反応と捉え, アレ ニウス型の整理を行った．Fig.2より，大気圧下おょび 減圧沸騰条件いずれにおいても，腐食速度は温度の逆数 に対して直線的に増加しているのがわかる。また，いず れの温度においても大気圧よりも減圧沸騰条件のほう が，腐食速度が大きくなることが示された。これは，上 野ら ${ }^{3)}$ の試験結果とも同傾向であり, 減圧沸騰により腐 食が加速するという結果は妥当であると考える.

\section{3 電気化学試験結果}

373 K でのカソード分極曲線を Fig. 3 に示す．腐食電 位は，大気圧下に比べ減圧沸騰条件では貴な電位になる ことがわかる．カソード分極曲線は，大気圧下ょり減圧 沸騰条件のほうが電流密度の上昇が見られる。アノード 分極曲線は，いずれの条件においても同一であり，圧力 条件の影響を受けなかった。

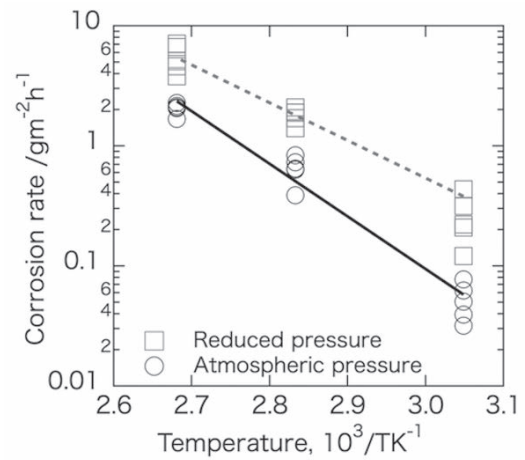

Fig. 2 Temperature dependence of corrosion rates of each batch.

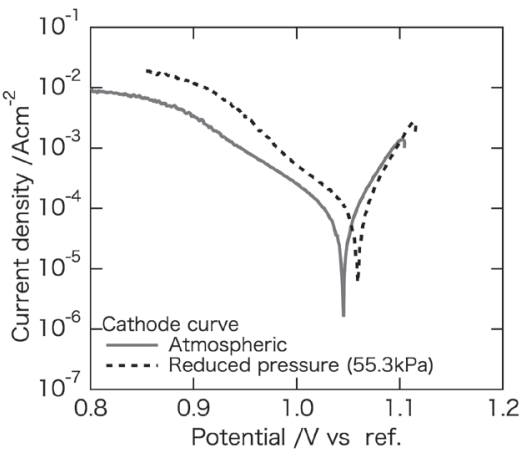

Fig. 3 Polarization curves on R-SUS304ULC in test solution simulated HALW at $373 \mathrm{~K}$; solid line is cathode curve of atmospheric condition and dot lines is cathode curve of boiling condition under reduced pressure at $55.3 \mathrm{kPa}$.

酸化性金属イオンを含有する硝酸溶液によるステンレ ス鋼腐食は，これまでの知見より硝酸の還元反応もしく は酸化性金属イオンの還元反応によるカソード反応支配 と考えられている ${ }^{1)}$. 分極曲線により示された腐食電位 の上昇およびカソード分極曲線の電流密度上昇は, 減圧 沸騰によるカソード反応の活発化を示しており, 浸漬腐 食試験より得られた腐食速度上昇と傾向が一致している。

\section{4. 考察}

減圧沸騰条件と大気圧下での非沸騰条件の大きな違い は，沸騰による蒸気泡の存在である，伝熱条件ではない 浸漬試験条件においても，ステンレス鋼表面，特に粒界 腐食のようなくぼみのある箇所では沸騰核が形成し, 蒸 気泡が発生しやすいと考えられる.この蒸気泡の成長や 離脱によって生じる腐食への影響として, 溶液の対流へ の影響と, 蒸気泡周辺の溶液組成変化が挙げられる.

まず，溶液の対流への影響では，ステンレス鋼表面で 発生した蒸気泡の離脱により, 溶液対流が促進される ${ }^{15)}$. 特に, 溶液バルクからステンレス鋼表面への溶液の流入 とともに，腐食に寄与する酸化性イオンの物質移動が促 進され，腐食の進行を促す要因となり得る。

次に，溶液組成の変化について考える。まず，蒸気泡 の主となる成分は $\mathrm{H}_{2} \mathrm{O}$ と考えられる。この溶液中の $\mathrm{H}_{2} \mathrm{O}$ が気相となるために, 気泡周辺の液相では, 相対的 に硝酸や金属イオンなどの酸化性イオン濃度が高くなる 領域が存在すると推測できる ${ }^{16)}$. ステンレス鋼表面で気 泡が発生すると, この酸化性イオン濃度が高い領域と接 液するため, カソード反応が促進され, 腐食が加速する と考えられる，さらに，溶液中に溶解している硝酸由来 の化学種のうちガス成分である窒素酸化物 $\left(\mathrm{NO}_{2}, \mathrm{NO}\right)$ は, 沸騰により気泡への移行が促進され, 気相中へ移行 しやすくなると考えられる。加藤ら ${ }^{17)}$ は $\mathrm{NO}_{2}$ や $\mathrm{NO} の$ 気相への排出により $\mathrm{HNO}_{2}$ 濃度が低下し, 硝酸の酸化還 元電位が上昇すると指摘している.このように，沸騰に より生じた溶液組成の変化がカソード反応促進に繋がっ た可能性がある.

以上のように, 蒸気泡の発生により生じた溶液中の変 化が，腐食電位の上昇やカソード反応促進に影響したさ れたと推定されるが, これらは浸漬腐食試験より確認さ 
れた減圧沸騰による腐食速度上昇の要因の全てとは言え ないため, 今後さらなる検討が必要と考える.

\section{5. 結}

\section{論}

本研究は，減圧沸騰がステンレス鋼腐食に与える影響 に着目し，実機環境を模擬した溶液を用いた腐食試験お よび電気化学試験により，以下のような結果を得た。

・ステンレス鋼腐食速度を浸漬腐食試験により取得し,

同じ溶液温度において，大気圧下の非沸騰溶液中より も飽和圧力まで減圧した沸騰溶液中のほうが，腐食速 度が大きくなる。

• $378 \mathrm{~K}$ での分極曲線より, 減圧沸騰により, 腐食電位 が貴な電位へ移行し，カソード分極曲線の電流密度が 上昇する。

以上より，同一温度において，非沸騰溶液中よりも減 圧沸騰溶液中のほうがステンレス鋼腐食は加速されるこ とを確認した.

\section{謝辞}

本研究は，原子力規制庁から国立研究開発法人日本原 子力研究開発機構が受託して実施した「商用再処理施設 の経年変化に関する研究」の成果の一部である.

\section{参 考 文 献}

1) M. Takeuchi, S. Takeda, T. Nagai and T. Koizumi, J.At. Energy Soc.Jpn, 4, 32 (2005)

2) F. Wada, Zairyo-to-Kankyo, 48, 771(1999).

3) F. Ueno, E. Irisawa and H. Abe, Proc. 61th Jpn. Conf. Materials and Environments, p.269, JSCE (2014).

4) H. Kajimura and H. Nagano, Corrosion, 48, 391(1992).
5) High Pressure Institute of Japan, “Code for Nuclear Fuels Reprocessing Facilities Materials Standard, HPIS C 108:2011 (2011).

6) Japan Nuclear Fuel Limited, "Revised Report on Leakage of Highly Active Liquid West in thermometer protective tube of Highly Active Liquid West Evaporator", Attachment No. 6 (2010).

7) Japan Nuclear Fuel Limited, "Revised Report on Leakage of Highly Active Liquid West in thermometer protective tube of Highly Active Liquid West Evaporator", Attachment No. 23 (2010).

8) Japan Atomic Energy Agency, "Handbook on Process and Chemistry of Nuclear Fuel Reprocessing Version 2", JAEA-Review, 2008-037 (2008).

9) Japan Nuclear Fuel Limited, "Report on Behavior of Radionuclide in Reprocessing facility”, JNFS R-91-001 (1996).

10) T. Motooka and M. Yamamoto, Zairyo-to-Kankyo, 57, 536 (2008).

11) Y. Arai, K. Mabuchi, T. Honda and H. Takahashi, Zairyoto-Kankyo, 51, 23(2002).

12) M. Pourbaix, "Atlas of Electrochemical Equilibria in Aqueous Solutions", 2nd Ed., p.234, NACE (1974).

13) C. Kato, F. Ueno, M. Yamamoto, Y. Hakamatsuka, Y. Ban, Y. Morita, G. Uchiyama, Y.Nojima and S. Fujine, Zairyo-toKankyo, 60, 69(2011).

14) Japan Nuclear Fuel Limited, “ Revised Report on Leakage of Highly Active Liquid West in thermometer protective tube of Highly Active Liquid West Evaporator", Attachment No. 29 (2010).

15) L-S.Fan and K.Tsuchiya, "Bubble Wake Dynamics in Liquids and Liquid Solid Suspensions", p.23 (1990).

16) H. Kajimura, H.Morikawa and H.Nagano, Boshoku-Gijutsu (presenty Zairyo-to-Kankyo), 36, 636 (1987).

17) C. Kato, K. Kiuchi and K. Sugimoto, Zairyo-to-Kankyo, 52, $44(2003)$.

(Manuscript received January 6, 2016; in final form February 3, 2016)

\section{要 旨}

使用済核燃料再処理施設の高レベル廃液濃縮缶の運転環境を模擬した試験を行い，酸化性金属イオンを 含む硝酸溶液中のステンレス鋼腐食に及ぼす沸騰の影響について評価した，浸漬腐食試験の結果から，同 じ溶液温度に抢いて, 大気圧下の非沸騰溶液中よりも減圧し沸騰させた溶液中のほうが腐食速度が大きく なることがわかった，さらに，分極曲線からも，沸騰により腐食電位が貴側へ移行し，カソード分極曲線 の電流密度が上昇することを確認した，以上より，同一温度において，減圧沸騰により腐食が加速される ことを確認した。

キーワード＼cjkstart使用済燃料再処理，硝酸，ステンレス鋼腐食，酸化性金属イオン，減圧沸騰 